\title{
EFEKTIVITAS APLIKASI ZOOM MEETING TERHADAP KUALITAS PEMBELAJARAN JARAK JAUH MAHASISWA PENDIDIKAN MASYARAKAT IKIP SILIWANGI ANGKATAN 2018
}

\author{
Wandi Kuswandi \\ Program Studi Pendidikan Masyarakat IKIP Siliwangi, Cimahi - Jawa Barat - Indonesia \\ wandikuswandi26@gmail.com
}

Received: Mei, 2021; Accepted: Mei, 2021

\begin{abstract}
This research is motivated by the application of social distancing which requires students to carry out online learning activities in order to prevent the transmission of COVID-19. The purpose of this study is to determine the effectiveness of the Zoom Meeting application used by students in distance learning during the COVID-19 pandemic. The theories used in this study include: (1). The theory of effectiveness, (2). Distance learning theory, and (3). The Concept of Using the Zoom Meeting Application. The method used is a descriptive method with a qualitative approach. Data obtained through interviews, observation and documentation. As for the research subjects, two lecturers and 12 students of public education class 2018 out of a total of 20 people. The results of this study show that the use of the Zoom Meeting application is very effective for online or distance learning, especially for the Community Education study program, IKIP Siliwangi, where the learning process can be done anywhere. In addition, there are several obstacles faced by students when using the Zoom Meeting application in distance learning, namely the unstable network.
\end{abstract}

Keywords: Learning, Effectiveness, Zoom Meeting

\begin{abstract}
Abstrak
Penelitian ini dilatar belakangi adanya penerapan social distancing yang mengharuskan mahasiswa melaksanakan kegiatan pembelajaran secara online dalam rangka mencegah penularan COVID-19. Tujuan penelitian ini yaitu mengetahui efektivitas aplikasi Zoom Meeting yang digunakan mahasiswa dalam pembelajaran jarak jauh pada masa pandemi COVID-19. Teori yang digunakan dalam penelitian ini diantaranya: (1). Teori efektivitas, (2). Teori pembelajaran jarak jauh, dan (3). Konsep Pemanfaatan Aplikasi Zoom Meeting. Metode yang digunakan adalah metode deskriptif dengan pendekatan kualitatif. Data yang diperoleh melalui wawancara, observasi dan dokumentasi. Adapun yang menjadi subjek penelitian adalah Dua Dosen dan 12 Mahasiswa pendidikan masyarakat angkatan 2018 dari jumlah keseluruhan 20 orang. Hasil dari penelitian ini bahwa penggunaan aplikasi Zoom Meeting sangat efektif untuk pembelajaran daring atau jarak jauh, khususnya bagi program studi Pendidikan Masyarakat, IKIP Siliwangi, dimana proses pembelajaran bisa dilakukan dimana saja. Selain itu ada beberapa kendala yang dihadapi mahasiswa saat menggunakan aplikasi Zoom Meeting pada pembelajaran jarak jauh yaitu tidak stabilnya jaringan yang ada.
\end{abstract}

Kata Kunci : Pembelajaran, Efektivitas, Zoom Meeting

How to Cite: Kuswandi, W. (2021). Efektivitas Aplikasi Zoom Meeting terhadap Kualitas Pembelajaran Jarak Jauh Mahasiswa Pendidikan Masyarakat. Comm-Edu (Community Education Journal), 4(2), 76-81. 


\section{PENDAHULUAN}

Pada akhir Tahun 2019 telah terjadi bencana besar di Negara Tiongkok, merebaknya Corona Virus, hingga menjalar ke seluruh dunia, termasuk Indonesia sebagai salah satu Negara yang terdampak. Permasalahan kesehatan ini, mempengaruhi aspek-aspek seperti perekonomian dan pendidikan menjadi terhambat keberlangsungannya. Maka dari itu pemerintah mengambil kebijakan dengan menerapkan Social Distancing untuk meminimalisir penularan COVID-19. Oleh karenanya untuk tetap dapat berlangsung kegiatan-kegiatan masyarakat di segala bidang, terutama kegiatan belajar mengajar baik di Sekolah maupun perguruan tinggi, dilakukan melalui daring (dalam jaringan).

Ketika melaksanakan pembelajaran secara online, tentunya memerlukan teknologi yang akan digunakan sebagai sarana media pembelajaran. Ada dua istilah dalam dunia pendidikan yaitu luring dan daring. Luring, artinya proses kegiatan belajar mengajar yang dilaksanakan bertatap muka secara langsung di dalam kelas, baik di sekolah atau pun kampus. Sedangkan daring, memiliki arti dalam jaringan adapun istilah dengan maksud maupun arti yang sama dapat disebut Electronic Learning disingkat E-learning. E-learning didefinisikan sebagai sebuah bentuk teknologi informasi yang diterapkan dibidang pendidikan berupa situs web yang dapat diakses dimana saja. Berdasarkan hasil penelitian yang dilakukan oleh Muali (2018) dalam (Septantiningtyas, 2018), Penggunaan teknologi diharapkan dapat meningkatkan minat belajar mahasiswa karena proses pembelajaran yang bersifat konvensional dirasa cenderung monoton. Selain itu, pembelajaran yang berpusat pada dosen dan buku akan membuat mahasiswa kurang berkreasi dalam pembelajaran di kelas, sedangkan pembelajaran daring bergantung pada teknologi sehingga mahasiswa dituntut untuk memiliki keterampilan dalam memanfaatkan gadget, agar proses pembelajaran dapat terlaksana secara optimal dan menjadikan mahasiswa yang kreatif, serta aktif.

Teknologi kini semakin mengalami perubahan yang signifikan, sehingga terciptanya berbagai OS seperti windows, IOS, android dan sebagainya. Selain itu teknologi dapat membantu kegiatan pembelajaran, dengan adanya aplikasi Google Meet, Google Classroom, Zoom Meeting dan lain sebagainya. Namun sebagian besar lembaga sekolah ataupun perguruan tinggi memilih aplikasi Zoom Meeting sebagai media pembelajaran utama, dimana dapat di install di OS IOS, windows, android dan sebagainya untuk memudahkan dalam proses pembelajaran mereka.

Berdasarkan situasi dan kondisi yang ada di program studi Pendidikan Masyarakat, termasuk kondisi pandemi yang memaksa mahasiswa dan dosen tidak bisa melakukan tatap muka, maka dipandang perlu untuk melaksanakan penelitian terkait efektivitas aplikasi Zoom Meeting terhadap kualitas pembelajaran jarak jauh mahasiswa Pendidikan Masyarakat IKIP Siliwangi angkatan 2018 yang menjadi subjek penelitian. Hal ini bermanfaat untuk memberikan deskripsi efektivitas pembelajaran daring dimasa pandemi COVID-19 pada mahasiswa program studi Pendidikan Masyarakat.

\section{METODE PENELITIAN}

Penelitian ini menggunakan Metode Deskriptif dengan pendekatan kualitatif. Pendekatan kualitatif adalah proses atau kegiatan penelitian pemahaman yang berdasarkan pada metodologi adalah menyelidiki suatu fenomena sosial dan masalah manusia untuk mendapatkan hasil yang akurat (Darmadi, 2014, hal. 184). Sedangkan metode deskriptif menurut Mukhtar (2013, hal. 10) adalah "Metode yang mendeskripsikan atau menggambarkan suatu penomena atau gejala yang dihubungkan dengan teori-teori yang relevan dengan teori yang digunakan pada variabel penelitian”. 
78 Kuswandi. Efektivitas Aplikasi Zoom Meeting terhadap Kualitas Pembelajaran Jarak jauh Mahasiswa Pendidikan Masyarakat

Penelitian ini dilaksanakan di Kampus IKIP Siliwangi yang beralamat di jalan. Terusan Jenderal Sudirman, Kecamatan Cimahi Tengah, Kota Cimahi. Subjek dari penelitian ini adalah Dua Dosen dan 12 Mahasiswa Pendidikan Masyarakat angkatan 2018 dari jumlah keseluruhan 20 orang. Adapun teknik pengumpulan data dilakukan dengan Observasi, Wawancara dan Dokumentasi.

Secara umum tahapan yang dilakukan dalam penelitian ini ada tiga tahap, sesuai dengan yang dikemukakan oleh Moleong (2013, hal. 127), yaitu :

1) Tahap Pra Lapangan, tahap ini merupakan tahap awal yang dilakukan peneliti dengan pertimbangan etika penelitian lapangan melalui tahap pembuatan rancangan usulan penelitian hingga menyiapkan perlengkapan penelitian. Dalam tahap ini peneliti diharapkan mampu memahami latar belakang penelitian dengan persiapan-persiapan diri yang mantap untuk masuk dalam lapangan penelitian. Pembuatan Instrumen yang terdiri dari pedoman wawancara.

2) Tahap pekerjaan lapangan, pada tahap ini peneliti berusaha menyiapkan diri untuk menggali dan mengumpulkan data-data untuk dibuat suatu analisis data memilih subjek yang akan menjadi narasumber dalam penelitian, mengadakan wawancara kepada mahasiswa untuk memperoleh informasi tentang aplikasi Zoom Meeting. Setelah itu mengolah data yang objektif dan tersusun.

3) Tahap analisis data, pada tahap ini dimulai dengan menelaah seluruh data yang tersedia dari wawancara. Analisis data dalam penelitian ini adalah Reduksi Data, Penyajian Data dan Penarikan Kesimpulan.

\section{HASIL DAN PEMBAHASAN}

\section{Hasil}

Berdasarkan hasil wawancara dengan dua dosen yang berinisial NR dan TR, serta 12 mahasiswa yang berinisial RMR, W, MAI, EFN, DNF, AAMR, ZSH, TOK, SY, HF, WA, dan MDA. Menurut pendapat WA, SY, MAI dan HF menyebutkan bahwa ia pertama kali menggunakan aplikasi Zoom Meeting, saat perkuliahan daring, sehingga sedikit terkendala saat memulai perkuliahan. Namun menurut kami pembelajaran daring menggunakan Zoom Meeting sangat efektif karena bisa dilakukan dimana saja. Pendapat lain diungkapkan oleh RMR, W, TOK dan DNF yang mengatakan bahwa penggunaan aplikasi Zoom Meeting perlu disosialisasikan lebih awal, sehingga mahasiswa tidak akan kesulitan saat pertama kali menggunakannya. Tetapi seiring berjalannya pembelajaran, mahasiswa mulai mengerti cara menggunakan aplikasi Zoom Meeting. Selain itu, materi yang disampaikan oleh dosen kepada mahasiswa juga jelas.

Pendapat lain yang hampir serupa diungkapkan oleh AAMR, ZSH, EFN dan MDA mengatakan bahwa menurut kami aplikasi Zoom Meeting bagus dan efektif. Pemakaian Zoom Meeting membuat mahasiswa enjoy sehingga lebih betah dan mampu menerima materi, walaupun dosen sedang berada di luar kampus atau dalam perjalanan. Sedangkan menurut NR dan TR selaku dosen, mengatakan bahwa menggunakan Zoom Meeting memudahkan dosen saat menyampaikan materi, selain itu dosen juga bisa melihat aktivitas mahasiswa saat pembelajaran, meskipun belajarnya jarak jauh.

Berdasarkan hasil pengamatan dilapangan, bahwa menggunakan aplikasi Zoom Meeting dinilai efektif dengan mengatasi ruang, waktu dan jarak. Penggunaan aplikasi Zoom Meeting dalam kegiatan mengajar dapat memudahkan pengajar (dosen) dalam mengontrol mahasiswa. Materi-materi pembelajaran yang diberikan dosen kepada mahasiswa dapat dilihat dan dicermati oleh mahasiswa. Selain itu, keunggulan aplikasi Zoom Meeting terdapat fitur share 
screen, dan memberikan kesempatan kepada salah satu peserta atau mahasiswa untuk menjadi (host) akan memudahkan saat memulai dan menerima permintaan user yang ingin bergabung pada konferensi Meeting yang sedang berlangsung.

Walaupun penggunaan aplikasi Zoom Meeting dapat mendukung pembelajaran jarak jauh (daring), akan tetapi ada kekurangan dalam proses pembelajaran. Kendala yang paling sering dialami oleh mahasiswa maupun dosen saat menggunakan aplikasi Zoom Meeting yaitu dari perangkat pengguna. Kendala tersebut berpengaruh terhadap kualitas audio visual secara langsung, berdasarkan hasil penelitian kendala tersebut yaitu jaringan internet yang kurang stabil sehingga proses penyampaian materi tidak dapat diterima dengan baik oleh semua mahasiswa.

\section{Pembahasan}

Pembahasan menguraikan hasil penelitian mengenai efektivitas aplikasi Zoom Meeting terhadap kualitas pembelajaran jarak jauh mahasiswa pendidikan masyarakat IKIP Siliwangi angkatan 2018. Berdasarkan hasil penelitian, menunjukan bahwa penggunaan aplikasi Zoom Meeting baru pertama kali dalam pembelajaran jarak jauh (daring). Menurut An Nisaa dalam (Liu, 2020) mengatakan Pembelajaran Online Zoom Meeting adalah Pembelajaran yang disampaikan secara elektronik yang dapat menunjang kebutuhan komunikasi dimanapun dan kapanpun dengan banyak orang tanpa harus bertemu fisik secara langsung antara mahasiswa dan pengajar dalam satu waktu yang sama.

Pada observasi awal, beberapa mahasiswa baru pertama kali menggunakan aplikasi Zoom Meeting, sehingga sedikit terkendala dalam segi penampilan. Dilihat dari proses pembelajaran, mahasiswa mampu mendengarkan materi dengan jelas tanpa ada hambatan. Pembelajaran pun bisa dilaksanakan meski berbeda tempat, karena pembelajaran menggunakan Zoom Meeting tidak terbatas oleh jarak dan waktu. Hal ini sesuai dengan pendapat yang dikemukakan oleh Kusuma dalam (Dwi Ismawati, 2020) Pembelajaran menggunakan Zoom Meeting untuk mengatasi keterbatasan antara pendidik dan anak didik, terutama dalam hal ruang dan waktu, dimana pendidik dan anak didik tidak harus berada dalam satu dimensi ruang dan waktu, pembelajaran dapat berjalan dengan mengabaikan kedua hal tersebut.

Pada observasi selanjutnya, mahasiswa mengunakan aplikasi Zoom Meeting untuk pembelajaran jarak jauh dikatakan efektif dan sangat praktis bagi para mahasiswa. Menurut Miarso (Rosyid, 2020) mengatakan bahwa efektivitas pembelajaran merupakan salah satu standar mutu pendidikan dan sering kali diukur dengan tercapainya tujuan atau dapat diartikan sebagai ketepatan dalam mengolah suatu situasi. Adapun dalam penggunaan aplikasi Zoom Meeting pada perkuliahan daring bisa dikatakan cukup efektif, karena sudah memenuhi hal-hal yang diperlukan, bila dibandingkan dengan yang lain.

Efektif yang dimaksud dalam penggunaan aplikasi ini yaitu efektif dalam segi waktu dan tempat. Penggunaan aplikasi Zoom Meeting dalam kegiatan mengajar dapat memudahkan pengajar (dosen) dalam mengontrol mahasiswa. Pada perkuliahan secara konvensional atau tatap muka sebelumnya sering dibatasi oleh ruang, sebagai contoh beberapa dosen yang sedang menjalankan tugas diluar kampus pada waktu yang seharusnya masuk kelas, mengakibatkan perkuliahan ditunda atau diganti di lain waktu. dengan aplikasi ini semua bisa diatasi, karena cukup mengaktifkan jaringan internet dan membuka aplikasi Zoom Meeting mahasiswa sudah dapat mengikuti kegiatan perkuliahan begitupun dengan dosen. 
80 Kuswandi. Efektivitas Aplikasi Zoom Meeting terhadap Kualitas Pembelajaran Jarak jauh Mahasiswa Pendidikan Masyarakat

Efektivitas pengguna (user), yaitu berbeda dengan aplikasi lain, dalam aplikasi Zoom Meeting ini tersedia fitur Group Video Converences, aplikasi Zoom Meeting menyediakan fitur konferensi video secara bersamaan, jika berlangganan pengguna Zoom Meeting untuk rapat video hingga 500 orang secara bersamaan. Jika memilih fitur yang gratis, pengguna dapat menyelenggarakan rapat video sebanyak 100 peserta dan dengan durasi waktu 40 menit. Melalui aplikasi Zoom Meeting selain menggunakan monitoring dari dosen juga efektif untuk mengatasi jumlah mahasiswa dalam satu kelas.

Efektivitas fasilitas, dengan adanya aplikasi Zoom Meeting ini mahasiswa atau dosen bisa menggunakan fitur transkip percakapan dan video call, mahasiswa dapat merekam percakapan dan video call tanpa harus mengaktifkan atau mengoperasikan aplikasi tambahan, cukup mengubah atau mengatur settingan yang ada diaplikasi Zoom Meeting dan dapat dilihat kembali diperangkat atau akun mereka masing-masing.

Selain keunggulan menggunakan aplikasi Zoom Meeting ternyata terdapat beberapa kekurangan. Seperti yang diungkapkan oleh Febriani (2019) Pembelajaran daring memiliki kelemahan ketika layanan internet lemah dan intruksi dosen kurang dipahami oleh mahasiswa. Berdasarkan hasil observasi, bahwa kendala yang dihadapi mahasiswa dalam pembelajaran daring menggunakan aplikasi Zoom Meeting adalah permasalahan jaringan data yang tersedia ketika mengakses aplikasi Zoom Meeting sering kali tidak baik, tidak stabil, sehingga proses penyampaian materi kurang jelas. Sedangkan, 8 orang mahasiswa mengakses aplikasi Zoom Meeting menggunakan layanan seluler dan 4 orang menggunakan layanan wifi. Hal ini menjadi tantangan tersendiri dalam penerapan pembelajaran jarak jauh di IKIP Siliwangi.

\section{KESIMPULAN}

Berdasarkan pemaparan dan hasil dapat diambil kesimpulan bahwa pemanfaatan aplikasi Zoom Meeting dimasa pandemi COVID-19 menjadi media pembelajaran jarak jauh untuk mahasiswa IKIP Siliwangi khususnya mahasiswa Pendidikan Masyarakat angkatan 2018 dan dosen. Penggunaan Zoom Meeting dinilai efektif mengatasi ruang, waktu, dan jarak, sebagai media pembelajaran jarak jauh dimasa pandemi COVID-19 sangat membantu dosen dan mahasiswa atau disebut pendidik dan peserta didik, walaupun disisi lain ada faktor-faktor penghambat seperti kurang baiknya jaringan internet dalam proses pembelajaran, sehingga proses penyampaian materi kurang jelas.

\section{DAFTAR PUSTAKA}

Darmadi, H. (2014). Metode Penelitian Pendidikan sosial. Bandung: Alpabet.

Dwi Ismawati, I. P. (2020). Efektivitas Pembelajaran Menggunakan Video Zoom Cloud Meeting di Era Pandemi Covid-19. Jurnal Pendidikan Anak Usia Dini, 5(1), 665-675. doi: 10.31004

Febrian, P. A. (2019). Blended Learning Syarah: Bagaimana Penerapan dan Persepsi Mahasiswa. Jurnal Gantang, 4(2), 111-119.

Liu, A. N. (2020). Pengaruh Pembelajaran Online Berbasis Zoom Cloud Meeting Terhadap Hasil Belajar Mahasiswa Fisika Universitas Flores. Jurnal JPFK, 6(1), 34-38.

Moleong, L. J. (2013). Metode Penelitian Kualitatif. Edisi Revisi. Bandung: PT. Remaja Rosdakarya.

Muali, S. I. (2018). Free Online Learning Based On Rich Internet Aplication; The Eksperimentation Of Critical Thinking About Student Learning Style. Journal Od 
Physics: Conference Series, 1114. doi:https://doi.org/10.1088/17426596/1114/1/012024

Mukhtar. (2013). Metode Praktis Penelitian Deskriptif Kualitatif. Jakarta Selatan: Referensi (GP Fres Group).

Rosyid, N. M. (2020). Penggunaan Aplikasi Zoom Cloud Meeting Dalam Kuliah Statistik Pendidikan Di Fakultas Agama Islam Universitas Islam Malang. Jurnal Pendidikan Islam, 5(11), 46-52.

Septantiningtyas, N. (2018). Pengaruh Pembelajaran Jarak Jauh Dengan Aplikasi Goole Class Terhadap Hasil belajar Mahasiswa. Edureligia, 2(2), 131-135. 